\title{
PENINGKATAN HASIL BELAJAR SISWA MENGGUNAKAN MODEL PEMBELAJARAN KOOPERATIF TIPE NUMBERED HEAD TOGETHER
}

\author{
*Ibnu Mansyur Hamdani \\ Akademi Teknologi Industri Dewantara Palopo, Palopo, Indonesia \\ *Email Korespondensi: ibnumansyur27@gmail.com
}

\section{INFO ARTIKEL}

Diterima 05 Juli 2021

Dipublikasikan 31 Juli 2021

\begin{abstract}
A B STR AK
Pelajaran matematika merupakan pelajaran yang masih dianggap sulit bagi siswa. Hal ini dapat ditinjau dari hasil belajar matematika siswa yang masih rendah. Rendahnya hasil belajar disebabkan oleh pemilihan metode pembelajaran yang kurang tepat. Salah satu cara untuk menanggulangi permasalahan tersebut adalah menggunakan model pembelajaran yang melibatkan peran siswa secara aktif dalam proses belajar mengajar. Model yang mampu melibatkan peran siswa secara aktif adalah model pembelajaran kooperatif, salah satunya adalah tipe Numbered Head Together (NHT). Model dengan tipe NHT mengutamakan adanya kelompokkelompok dengan anggota yang memiliki tingkat kemampuan yang berbeda-beda. Penelitian ini dilakukan pada siswa kelas VIIIA SMP Kartika XX-2 Wirabuana Makassar. Faktor utama yang menjadi perhatian untuk diselidiki adalah nilai harian siswa, kemampuan siswa, dan hasil tes siswa. Penerapan model NHT dilaksanakan dalam 2 siklus, di mana setiap siklus memiliki 4 tahap. Tahap tersebut adalah perencanaan, aksi, observasi, dan refleksi. Hasil observasi pada siklus 2 menunjukkan perubahan yang positif pada siswa. Perubahan tersebut dilihat dari segi prestasi, interaksi, sikap, dan kemampuan siswa dalam menyelesaikan soal matematika secara individu sebagai dampak positif terhadap hasil belajar kelompok. Skor rata-rata hasil belajar matematika meningkat, yaitu 82,14 dan berada pada kategori tinggi dengan persentase ketuntasan sebesar $86,48 \%$.
\end{abstract}

\section{IMPROVING STUDENT LEARNING OUTCOMES USING NUMBERED HEAD TOGETHER TYPE OF COOPERATIVE LEARNING MODEL}

\begin{abstract}
Mathematics is a lesson that is still considered difficult for students. This can be seen from the students' mathematics learning outcomes which are still low. The low learning outcomes are caused by the selection of an inappropriate learning method. One way to overcome these problems is to use a learning model that involves the active role of students in the teaching and learning process. A model that is able to actively involve students' roles is a cooperative learning model, one of which is the Numbered Head Together (NHT) type. The model with the NHT type prioritizes the existence of groups with members who have different levels of ability. This research was conducted on students of class VIIIA SMP Kartika XX-2 Wirabuana Makassar. The main factors that were of concern to be investigated are students' daily scores, students' abilities, and student test results. The application of the NHT model was carried out in 2 cycles, where each cycle had 4 stages. These stages were planning, action, observation, and reflection. The results of observations in 2 nd cycle showed positive changes in students. These changes were seen in
\end{abstract}


terms of students' achievement, interaction, attitudes, and abilities in solving mathematics problems individually as a positive impact on group learning outcomes. The average score of mathematics learning outcomes increased, which was 82.14 , and was in the high category with a mastery percentage of $86.48 \%$.

Keywords: Numbered Head Together, Mathematics Learning Outcomes

\section{Pendahuluan}

Perkembangan ilmu pengetahuan dan teknologi telah membawa perubahan yang berarti bagi kehidupan manusia, baik dari segi ekonomi, sosial-budaya maupun segi pendidikan. Pembelajaran yang merupakan inti dari pendidikan juga mengalami perubahan. Perubahan itu merupakan perubahan paradigma dari pembelajaran yang berpusat pada guru menjadi pembelajaran yang berpusat pada siswa. Perubahan paradigma pembelajaran tersebut memicu perbaikan mutu pendidikan di Indonesia. Berbagai upaya yang dilakukan untuk memperbaiki dan meningkatkan mutu pendidikan di Indonesia seakan tidak pernah berhenti. Banyak agenda reformasi dalam pendidikan yang telah, sedang, dan akan dilaksanakan. Salah satunya yaitu reformasi di sektor kurikulum. Namun, pembaharuan kurikulum tidak akan memberi pengaruh berarti bila tidak dibarengi dengan adanya perubahan pola kegiatan pembelajaran yang mengacu pada paradigma pendidikan kita saat ini.

Pembelajaran yang berpusat pada siswa ini menekankan bahwa pengetahuan sebaiknya dikonstruk sendiri oleh siswa. Dengan demikian, peranan utama guru untuk tercapainya tujuan pembelajaran adalah membimbing, mengembangkan, dan mengelola kegiatan pembelajaran siswa (Sanjani, 2020). Para pelaku pembelajaran yaitu guru, seyogianya melakukan perubahan pola kegiatan pembelajaran di kelas seperti pemilihan metode pembelajaran yang tepat, pengelolaan kegiatan belajar mengajar yang dapat meningkatkan motivasi siswa serta peningkatan pemberian penguatan (reinforcement) pada siswa. Hal yang perlu diperhatikan oleh guru dalam peningkatan hasil belajar di kelas adalah pemilihan metode pembelajaran. Penggunaan metode mengajar yang tepat memengaruhi tujuan, isi, proses belajar mengajar, dan kegiatan belajar mengajar (Sabri, 2007) dan (Widodo, Sukiswo, \& Putra, 2011)

Matematika merupakan salah satu mata pelajaran yang masih dianggap sulit bagi siswa (Siregar, 2017), khususnya di sekolah menengah pertama. Pada umumnya kesulitan merupakan kondisi tertentu yang ditandai dengan adanya hambatan-hambatan dalam kegiatan untuk mencapai suatu tujuan, sehingga memerlukan usaha yang lebih berat lagi untuk dapat mengatasinya. Kesulitan belajar dapat diartikan sebagai suatu kondisi dalam proses belajar yang ditandai oleh adanya hambatan-hambatan tertentu untuk menghasilkan hasil belajar (Mulyadi, 2010). Jadi, dapat dikatakan bahwa yang dimaksud dengan kesulitan belajar adalah keadaan dimana siswa mengalami hambatan dalam belajar, sehingga tidak memenuhi harapan-harapan yang diinginkan dalam berbagai jenis mata pelajaran termasuk Matematika.

Rata-rata hasil belajar matematika siswa yang merupakan subjek penelitian masih tergolong rendah, yaitu 65. Rendahnya hasil belajar siswa ini disebabkan oleh beberapa faktor salah satunya adalah kesalahan guru dalam pemilihan metode yang tidak tepat, gaya mengajar, serta pengetahuan dan keterampilan yang terbatas dalam menyampaikan materi yang dapat menyebabkan siswa sulit untuk memahami pelajaran matematika. Siswa diajarkan dengan metode yang tidak menarik karena guru hanya menerangkan sedangkan siswa hanya mencatat. Hal ini dapat menjadi penyebab terhambatnya kreativitas dan kemandirian siswa sehingga menurunkan prestasi belajar siswa.

Salah satu cara yang dapat dilakukan untuk menanggulangi permasalahan tersebut, yaitu dengan memilih model pembelajaran yang melibatkan peran siswa secara aktif dalam kegiatan belajar mengajar. Atas dugaan di atas, maka peneliti bersama-sama dengan guru sepakat untuk menawarkan suatu tindakan alternatif untuk mengatasi masalah yang ada berupa penerapan model pembelajaran lain yang lebih mengutamakan keaktifan siswa dan memberi kesempatan siswa untuk mengembangkan potensinya secara maksimal. Model Pembelajaran yang mampu melibatkan peran siswa secara aktif adalah model pembelajaran kooperatif. Model pembelajaran ini mengutamakan adanya kelompok-kelompok, di mana dalam setiap kelompok memiliki anggota dengan tingkat kemampuan yang berbeda-beda (tinggi, sedang, dan rendah) (Daryanto \& Rahardjo, 2012). 
Salah satu model pembelajaran kooperatif adalah Numbered Head Together (NHT) (Fonica, Gusmaweti, \& Deswati, 2013) dan (Manurung, Widyastuti, Mulyani, \& Saputro, 2013). Model Pembelajaran ini dikembangkan oleh Spencer Kagen (1993) yang mampu mengaktifkan siswa untuk menelaah materi dan mengecek pemahaman mereka terhadap materi pelajaran tersebut (Taniredja, Pujiati, \& Nyata, 2012). Dalam pembelajaran kooperatif tipe NHT, siswa lebih bertanggung jawab terhadap tugas yang diberikan karena dalam pembelajaran kooperatif tipe NHT siswa dalam kelompok diberi nomor yang berbeda. Setiap siswa dibebankan untuk menyelesaikan soal sesuai dengan nomor anggota mereka. Tetapi, pada umumnya mereka harus mampu mengetahui dan menyelesaikan semua soal yang ada di LKS (Alie, 2013).

Dalam proses pembelajaran kooperatif tipe NHT siswa aktif bekerja dalam kelompok. Mereka bertanggungjawab penuh terhadap soal yang diberikan. Misalnya, siswa yang bernomor urut 2 dalam kelompoknya mempertanggungjawabkan soal nomor 2 dan seterusnya. Walaupun pada saat presentasi mereka bisa ditunjuk untuk mengerjakan nomor lain. Sedangkan pada model pembelajaran kooperatif yang lain terkadang siswa saling berharap kepada teman kelompoknya yang lebih pintar. Dalam pembelajaran kooperatif tipe Student Team Achievement Division (STAD) misalnya, siswa hanya disuruh bekerja dalam kelompok dan pertanggungjawabannya secara kelompok pula. Artinya, siswa kurang aktif dalam kelompok.

Pembelajaran kooperatif tipe NHT juga dinilai lebih memudahkan siswa berinteraksi dengan temantemannya dalam kelas dibandingkan dengan model pembelajaran langsung yang selama ini diterapkan oleh guru. Pada model pembelajaran kooperatif tipe NHT siswa perlu berkomunikasi satu sama lain, sedangkan pada model pembelajaran langsung siswa duduk berhadap-hadapan dengan guru dan terus memperhatikan gurunya.

Berdasarkan pemikiran inilah, penelitian ini dilakukan untuk meningkatkan hasil belajar matematika siswa pada Sekolah Menengah Pertama (SMP) Kartika XX-2 Wirabuana Makassar menggunakan model pembelajaran kooperatif tipe NHT.

\section{Metode Penelitian}

Penelitian ini dilaksanakan di SMP Kartika XX-2 Wirabuana Makassar. Subjek dalam penelitian ini adalah siswa kelas VIIIA SMP Kartika XX-2 Wirabuana Makassar yang berjumlah 37 orang yang terdiri dari 17 orang laki-laki dan 20 orang perempuan dengan kemampuan yang heterogen. Materi yang digunakan dalam penelitian ini adalah materi Sistem Persamaan Linier Dua Variabel (SPLDV).

Faktor-faktor utama yang menjadi perhatian untuk diselidiki dalam penelitian ini, sebagai berikut:

a. Faktor input: melihat atau memperhatikan nilai harian siswa sebelumnya.

b. Faktor proses: melihat sejauh mana siswa mampu menyelesaikan soal-soal latihan matematika, baik dalam kelompok maupun mandiri.

c. Faktor output: melihat hasil yang diperoleh siswa setelah diberikan tes akhir setiap siklus setelah pembelajaran dengan model pembelajaran kooperatif tipe Numbered Head Together.

Penelitian ini terdiri dari 2 siklus. Dalam setiap siklus, terdiri dari 4 tahap yakni tahap perencanaan, tahap pelaksanaan, tahap observasi dan evaluasi dan tahap refleksi. Desain dan model penelitian tindakan kelas dalam penelitian tindakan ini ditunjukkan pada Gambar . 


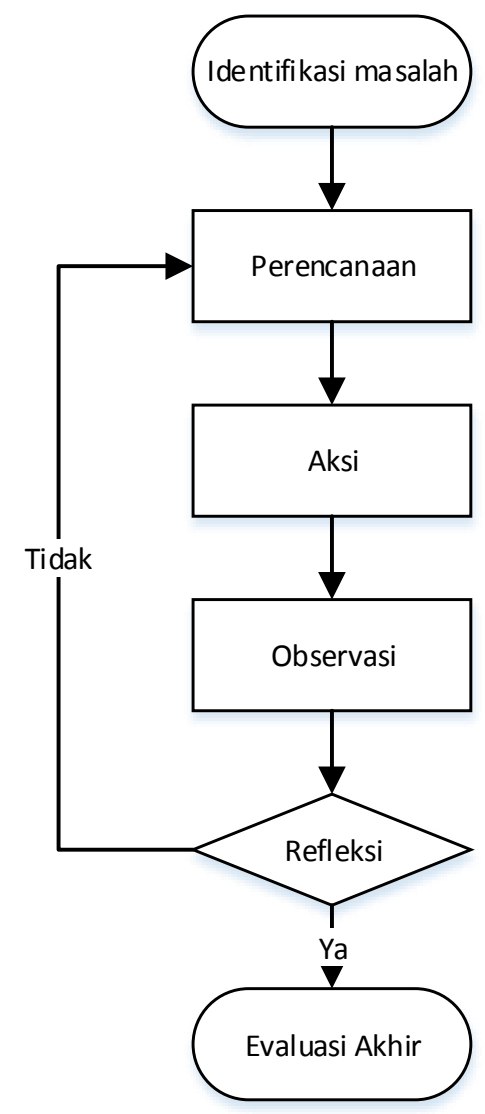

Gambar I. Prosedur Penelitian Tindakan Kelas.

\subsection{Siklus 1}

Siklus pertama ini berlangsung selama 3 kali pertemuan yang digunakan sebagai proses pembelajaran dan 1 kali pertemuan sebagai tes siklus 1 .

\subsubsection{Tahap Perencanaan}

Kegiatan-kegiatan yang dilakukan dalam tahap perencanaan ini adalah sebagai berikut:

a. Menelaah materi pelajaran matematika kelas VIII semester ganjil.

b. Menentukan materi yang akan diajarkan pada siklus I.

c. Membuat Rencana Pelaksanaan Pembelajaran (RPP).

d. Membuat soal-soal yang akan diberikan pada tiap akhir siklus.

e. Menyusun kelompok belajar siswa yang heterogen, yaitu terdiri dari 5-6 siswa tiap kelompok.

f. Membuat lembar observasi untuk melihat bagaimana kondisi siswa pada saat proses belajar mengajar di kelas berlangsung yang meliputi kehadiran, keaktifan mengikuti pelajaran, rasa percaya diri, keterampilan siswa dalam melakukan kerjasama dengan anggota kelompok, dan keberanian dalam mempresentasikan hasil kerja kelompoknya dan menanggapi presentasi kelompok lain.

\subsubsection{Tahap Pelaksanaan Tindakan (Aksi)}

Kegiatan yang dilaksanakan pada tahap ini disesuaikan dengan rencana yang telah disusun dalam rencana pembelajaran. Secara umum, langkah-langkah yang dilakukan dalam tahap ini adalah:

a. Penyajian materi dengan penerapan model pembelajaran kooperatif tipe NHT, dengan tahap-tahap sebagai berikut.

1. Menyampaikan tujuan pembelajaran yang akan dicapai

2. Memberikan apersepsi 
3. Menjelaskan materi disertai contoh kemudian memberi kesempatan pada siswa untuk bertanya Membimbing pelatihan awal

4. Membagi siswa menjadi beberapa kelompok yang beranggotakan 5-6 orang dan memberi nomor kepada setiap siswa dalam kelompok dan nama kelompok yang berbeda.

5. Membagikan LKS kepada setiap siswa sebagai bahan yang akan dipelajari.

6. Menyebut satu nomor dan para siswa dari setiap kelompok dengan nomor yang sama mengangkat tangan dan menyiapkan jawaban kepada siswa di kelas.

7. Memberikan kesimpulan atau jawaban akhir dari semua pertanyaan yang berhubungan dengan materi yang disajikan.

8. Memberikan penghargaan berupa kata-kata pujian pada siswa dan memberi nilai yang lebih tinggi pada kelompok yang hasil belajarnya lebih baik.

b. Pemberian tes akhir pada setiap siklus.

\subsubsection{Tahap Observasi dan Evaluasi}

Kegiatan yang dilakukan pada tahap ini adalah:

a. Mengamati setiap kegiatan siswa melalui lembar observasi yang dilakukan oleh observer. Observer telah dibimbing mengenai langkah-langkah pelakasanaan pembelajaran kooperatif tipe NHT (Numbered Head Together).

b. Mengevaluasi hasil belajar siswa dengan tes hasil belajar di akhir setiap siklus.

\subsubsection{Tahap Refleksi}

Refleksi merupakan aktivitas melihat berbagai kekurangan yang dilaksanakan guru selama tahap tindakan. Di tahap ini, hal-hal yang belum tuntas ataupun yang perlu diperbaiki dikaji, sehingga dapat dijadikan dasar penyusunan rencana ulang pada pembelajaran siklus berikutnya.

\subsection{Siklus 2}

Siklus ini akan dilaksanakan selama 4 kali pertemuan yang digunakan sebagai proses pembelajaran dan 1 kali pertemuan sebagai tes siklus. Aktivitas-aktivitas yang akan dilaksanakan pada siklus kedua ini merupakan hasil refleksi dari siklus pertama. Oleh karena itu langkah-langkah yang dilakukan relatif sama dengan siklus pertama dengan mengadakan beberapa perbaikan sesuai dengan kenyataan yang telah ditemukan di lapangan.

\subsubsection{Perencanaan}

Tahap perencanaan pada siklus kedua, aktivitas perencanaan pada siklus pertama dikembangkan dan dilanjutkan.

\subsubsection{Tindakan}

Pelaksanaan tindakan yang dilakukan pada siklus II adalah mengulangi kembali tahap-tahap yang dilakukan pada siklus I sambil mengadakan perbaikan atau penyempurnaan sesuai hasil yang diperoleh pada siklus pertama.

\subsubsection{Observasi dan Evaluasi}

Aktivitas observasi pada siklus kedua mengikuti teknik observasi pada siklus pertama, dan melakukan proses evaluasi. 


\subsubsection{Refleksi}

Data yang diperoleh dari hasil observasi dikumpulkan dan dianalisis. Dari hasil tersebut peneliti merefleksi diri dengan melihat kegiatan-kegiatan yang dilakukan. Dari hasil analisis tersebut peneliti dapat membuat evaluasi akhir terhadap seluruh hasil pembelajaran matematika setelah diterapkan model pembelajaran kooperatif tipe Numbered Head Together

\section{Hasil dan Pembahasan}

Data dalam penelitian ini diambil dari 37 orang siswa yang terdiri dari 17 orang laki-laki dan 20 orang perempuan. Penelitan tindakan kelas yang dilakukan di kelas VIIIA SMP Kartika XX-2 Wirabuana Makassar dimaksudkan untuk mengungkap hasil penelitian dan pembahasan tentang berbagai hal yang berkaitan dengan perencanaan dan pelaksanaan penelitian, hasil yang diperoleh dan implikasi tindakan yang dilakukan untuk mengadakan peningkatan sebagai refleksi yang diperoleh dari analisis data.

\subsection{Siklus 1}

Hasil penelitian ini Berdasarkan pada hasil analisis deskriptif dengan menggunakan SPSS Pawstatics 18, hasil belajar matematika siswa kelas VIII SMP Kartika XX-2 Wirabuana Makassar pada siklus I yang disajikan pada Tabel 1, sebagai berikut:

Tabel 1. Statistik skor hasil belajar matematika siklus 1

\begin{tabular}{lc}
\hline \multicolumn{1}{c}{ Statistik } & Nilai Statistik \\
\hline Subjek Penelitian & 37 \\
Rata-rata & 70 \\
Standar Deviasi & 17,6 \\
Median & 72,2 \\
Variansi & 310,383 \\
Skor Maksimum & 97,2 \\
Skor Minimum & 20 \\
Rentang Skor & 77,2 \\
\hline
\end{tabular}

Hasil belajar matematika siswa dikelompokkan ke dalam lima kategori. Berdasarkan kategori tersebut, distribusi frekuensi dan persentase skor diperoleh yang ditunjukkan pada Tabel 2 dan gambar 2, berikut:

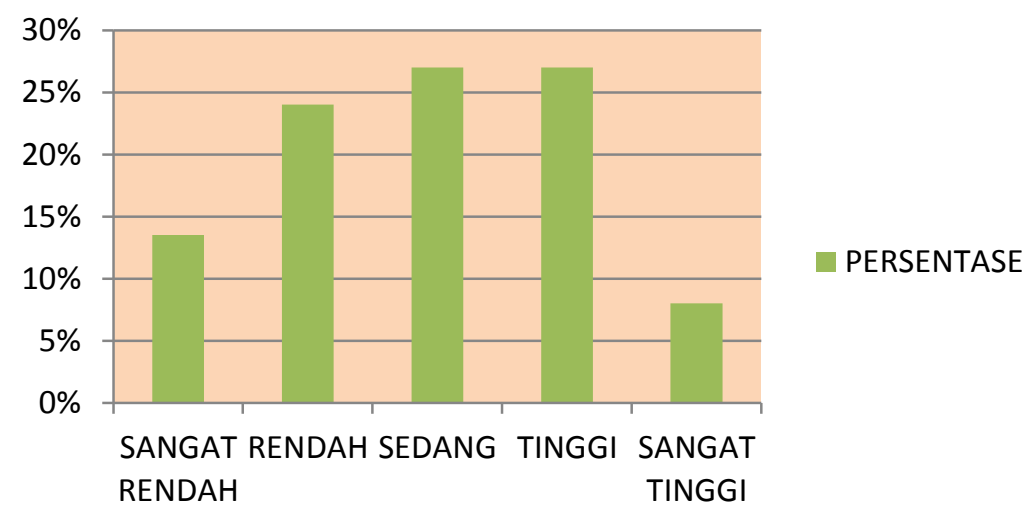

Gambar II. Persentase hasil belajar matematika siklus 1 
Tabel II. Frekuensi dan persentase hasil belajar matematika siklus 1

\begin{tabular}{ccccc}
\hline No. & Rentang Skor & Kategori & Frekuensi & Persentase \\
\hline 1 & $0-54$ & Sangat rendah & 5 & 14 \\
2 & $55-69$ & Rendah & 9 & 24 \\
3 & $70-79$ & Sedang & 10 & 27 \\
4 & $80-89$ & Tinggi & 10 & 27 \\
5 & $90-100$ & Sangat tinggi & 3 & 8 \\
\hline
\end{tabular}

Berdasarkan Tabel 1 dan Tabel, rata-rata hasil belajar matematika siswa kelas VIIIA SMP Kartika XX-2 Wirabuana Makassar setelah dilakukan tindakan pembelajaran kooperatif tipe Numbered Head Together (NHT) pada siklus I berada dalam kategori "sedang". Skor rata-rata dari hasil belajar matematika adalah 70 dari skor ideal 100 yang mungkin dicapai oleh siswa dengan standar deviasi 17,6. Data ini menunjukkan bahwa tingkat penguasaan materi SPLDV yang dipelajari pada siklus I sebesar 70. Selain itu, Median berpusat pada skor 72,2 , artinya $50 \%$ skor berada di bawah atau sama dengan 72,2 dan $50 \%$ skor siswa diatas atau sama dengan 72,2 .

Jika ditinjau dari nilai kriteria ketuntasan minimal (KKM) yaitu 70, sekolah sudah berada pada standar yang diharapkan. Namun, belum mencapai target keberhasilan yaitu $85 \%$ siswa mencapai minimal nilai kkm (70). Secara kuantitatif, ketuntasan hasil belajar matematika siswa setelah pemberian tindakan pada siklus 1 dapat dilihat pada Tabel, berikut:

Tabel III. Frekuensi dan persentase ketuntasan pada siklus 1

\begin{tabular}{cccc}
\hline Skor & Kategori & Frekuensi & Persentase (\%) \\
\hline$<70$ & Tidak Tuntas & 14 & 37,8 \\
$\geq 70$ & Tuntas & 23 & 62,2 \\
\hline & Jumlah & $\mathbf{3 7}$ & $\mathbf{1 0 0}$
\end{tabular}

Hasil belajar matematika siswa bergantung dari aktivitas dan sikap siswa selama proses pembelajaran di setiap pertemuan. Data tersebut diperoleh dari hasil observasi aktivitas siswa selama proses pembelajaran pada siklus 1. Data tersebut disajikan pada Tabel, berikut:

Tabel IV. Hasil observasi aktivitas siswa siklus 1

\begin{tabular}{|c|c|c|c|c|c|c|c|}
\hline \multirow{2}{*}{ NO } & \multirow{2}{*}{ KOMPONEN YANG DIAMATI } & \multicolumn{4}{|c|}{ PERTEMUAN } & \multirow{2}{*}{$\begin{array}{l}\text { RATA- } \\
\text { RATA }\end{array}$} & \multirow{2}{*}{$\begin{array}{c}\text { PERSENTASE } \\
\%\end{array}$} \\
\hline & & 1 & 2 & 3 & 4 & & \\
\hline \multirow{2}{*}{1} & Siswa yang hadir pada saat proses & 3 & 3 & 3 & 3 & \multirow{2}{*}{36,75} & \multirow{2}{*}{99,3} \\
\hline & pembelajaran. & 7 & 6 & 7 & 7 & & \\
\hline \multirow{2}{*}{2} & Siswa yang memperhatikan selama & 1 & 1 & 2 & \multirow{4}{*}{ 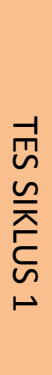 } & \multirow{2}{*}{20} & \multirow{2}{*}{54,1} \\
\hline & proses pembelajaran berlangsung. & 9 & 8 & 3 & & & \\
\hline 3 & $\begin{array}{l}\text { Siswa yang mengajukan pertanyaan } \\
\text { mengenai materi yang belum } \\
\text { dipahami. }\end{array}$ & 3 & 3 & 4 & & 10 & 27 \\
\hline 4 & $\begin{array}{l}\text { Siswa yang menjawab } \\
\text { pertanyaan/soal yang diajukan oleh } \\
\text { guru. }\end{array}$ & 2 & 3 & 3 & & 2,67 & 7,2 \\
\hline 5 & Siswa yang menjawab & 3 & 2 & 4 & & 3 & 8,1 \\
\hline
\end{tabular}




\begin{tabular}{|c|c|c|c|c|c|c|}
\hline & $\begin{array}{l}\text { pertanyaan/soal yang diajukan oleh } \\
\text { guru. }\end{array}$ & & & & & \\
\hline 6 & $\begin{array}{l}\text { Siswa yang memberikan bantuan } \\
\text { kepada teman kelompok yang } \\
\text { mengalami kesulitan. }\end{array}$ & 3 & 4 & 4 & 3,7 & 9,9 \\
\hline 7 & $\begin{array}{l}\text { Siswa yang mengajukan tanggapan } \\
\text { saat pembahasan soal. }\end{array}$ & 2 & 2 & 3 & 2,3 & 6,3 \\
\hline \multirow{2}{*}{8} & Siswa yang mengerjakan Pekerjaan & 1 & 2 & 2 & \multirow{2}{*}{24,33} & \multirow{2}{*}{65,77} \\
\hline & Rumah (PR). & 8 & 6 & 9 & & \\
\hline
\end{tabular}

Pada siklus 1, guru membentuk kelompok heterogen yang beranggotakan 5-6 orang. Pembagian tersebut didasarkan pada kemampuan akademik dan jenis kelamin. Selain itu, guru menyampaikan tujuan dan memberikan motivasi kepada siswa untuk terus belajar dan memperhatikan pelajaran yang diberikan.

Setelah pelaksanaan pembelajaran menggunakan model kooperatif tipe NHT selama empat pertemuan. Keaktifan siswa dalam proses belajar mengajar agak meningkat, walaupun masih ada beberapa siswa yang masih melakukan aktivitas lain dan tidak memperhatikan pelajaran. Selain itu, masih ada beberapa siswa yang bersikap pasif dan belum beranin untuk berbicara di depan kelas.

Berdasarkan tes hasil belajar siklus 1, terdapat 23 siswa dari 37 orang yang mencapai ketuntasan. Ketuntasan tersebut sebesar $62,2 \%$, di mana persentase tersebut masih di bawah dari target keberhasilan (85\%). Hal tersebut dikarenakan waktu dalam proses pembelajaran masih belum efektif. Tidak efektifnya penggunaan waktu dikarenakan masih banyak siswa yang kurang aktif dalam proses diskusi dan belum berani bertanya ketika mengalami kesulitan. Oleh karena itu, diperlukan tindakan perbaikan pembelajaran lebih lanjut dengan memperhitungkan keefektifan waktu, serta memotivasi siswa agar lebih aktif dalam bertanya dan dikusi.

\subsection{Siklus 2}

Hasil analisis deskriptif dari hasil belajar matematika siswa kelas VIIIA SMP Kartika XX-2 Wirabuana Makassar pada siklus 2, disajikan pada Tabel V, berikut:

Tabel V. Statistik skor hasil belajar matematika siklus 2

\begin{tabular}{lc}
\hline \multicolumn{1}{c}{ Statistik } & Nilai Statistik \\
\hline Subjek Penelitian & 37 \\
Rata-rata & 82,14 \\
Standar Deviasi & 10,7 \\
Median & 82,9 \\
Variansi & 114,616 \\
Skor Maksimum & 100 \\
Skor Minimum & 58,5 \\
Rentang Skor & 41,5 \\
\hline
\end{tabular}

Skor hasil belajar tersebut jika dikelompokkan dalam lima kategori, maka diperoleh distribusi frekuensi skor pada Tabel 4 dan histogram hasil belajar tersebut ditunjukkan pada gambar 3 berikut:

Tabel VI. Frekuensi dan persentase ketuntasan pada siklus 2

\begin{tabular}{ccccc}
\hline No. & Rentang Skor & Kategori & Frekuensi & Persentase (\%) \\
\hline 1 & $0-54$ & Sangat rendah & 0 & 0 \\
2 & $55-69$ & Rendah & 5 & 14 \\
3 & $70-79$ & Sedang & 6 & 16 \\
4 & $80-89$ & Tinggi & 17 & 46 \\
5 & $90-100$ & Sangat tinggi & 9 & 24 \\
\hline
\end{tabular}




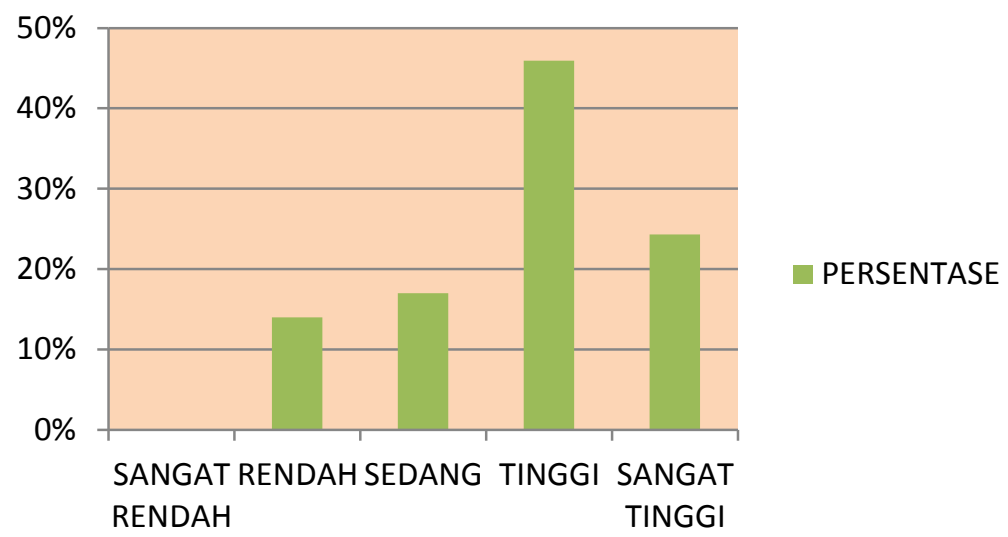

Gambar III. Persentase hasil belajar matematika siklus 2

Berdasarkan Tabel V dan Tabel, dapat disimpulkan bahwa hasil belajar matematika siswa kelas VIIIA SMP Kartika XX-2 Wirabuana Makassar setelah dilakukan tindakan pembelajaran kooperatif tipe Numbered Head Together (NHT) pada siklus II berada dalam kategori "Tinggi" dengan skor rata-rata 82,14 dari skor ideal 100 yang mungkin dicapai oleh siswa dengan standar deviasi 10.7. Data ini menunjukkan bahwa tingkat penguasaan materi SPLDV yang dipelajari pada siklus II sebesar 82,14. Selain itu, median berpusat pada skor 82,9, artinya 50\% skor siswa berada di bawah atau sama dengan 82,9 dan 50\% skor siswa berada di atas atau sama dengan 82,9. Secara kuantitatif, hasil belajar matematika siswa pada siklus 2 ditunjukkan pada Tabel, Data aktivitas siswa pada siklus 2 mengalami peningkatan bila dibandingkan dengan data aktivitas siswa pada siklus 1. Data aktivitas tersebut ditunjukkan pada Tabel.

Tabel VII. Frekuensi dan persentase ketuntasan pada siklus 2

\begin{tabular}{cccc}
\hline Skor & Kategori & Frekuensi & Persentase (\%) \\
\hline$<70$ & Tidak Tuntas & 5 & 13,52 \\
$\geq 70$ & Tuntas & 32 & 86,48 \\
\hline & Jumlah & $\mathbf{3 7}$ & $\mathbf{1 0 0 , 0 0}$
\end{tabular}

Tabel VIII. Hasil observasi aktivitas siswa siklus 2

\begin{tabular}{|c|c|c|c|c|c|c|c|}
\hline \multirow{2}{*}{ NO } & \multirow{2}{*}{ KOMPONEN YANG DIAMATI } & \multicolumn{4}{|c|}{ PERTEMUAN } & \multirow{2}{*}{$\begin{array}{l}\text { RATA- } \\
\text { RATA }\end{array}$} & \multirow{2}{*}{$\begin{array}{l}\text { PERSENTASE } \\
\% \\
\end{array}$} \\
\hline & & 1 & 2 & 3 & 4 & & \\
\hline \multirow{2}{*}{1} & Siswa yang hadir pada saat proses & 3 & 3 & 3 & 3 & \multirow{2}{*}{36,25} & \multirow{2}{*}{97,97} \\
\hline & pembelajaran. & 7 & 4 & 7 & 7 & & \\
\hline \multirow{2}{*}{2} & Siswa yang memperhatikan selama & 2 & 2 & 2 & & \multirow{2}{*}{23,67} & \multirow{2}{*}{63,96} \\
\hline & $\begin{array}{l}\text { proses pembelajaran berlangsung. } \\
\text { Siswa vang mengajukan pertanyaan }\end{array}$ & 4 & 2 & 5 & & & \\
\hline 3 & $\begin{array}{l}\text { mengenai materi yang belum } \\
\text { dipahami. }\end{array}$ & 5 & 8 & 9 & 而 & 7,33 & 19,82 \\
\hline 4 & $\begin{array}{l}\text { Siswa yang menjawab } \\
\text { pertanyaan/soal yang diajukan oleh } \\
\text { guru. }\end{array}$ & 4 & 4 & 4 & $\frac{n}{\bar{\lambda}}$ & 4 & 10,8 \\
\hline 5 & $\begin{array}{l}\text { Siswa yang menjawab } \\
\text { pertanyaan/soal yang diajukan oleh } \\
\text { guru. }\end{array}$ & 4 & 3 & 3 & & 3,33 & 9 \\
\hline 6 & Siswa yang memberikan bantuan & 4 & 4 & 4 & & 4 & 10,8 \\
\hline
\end{tabular}


kepada teman kelompok yang

mengalami kesulitan.

7

Siswa yang mengajukan tanggapan

saat pembahasan soal.

345

4

10,8

8

Siswa yang mengerjakan Pekerjaan

$\begin{array}{lll}2 & 2 & 3\end{array}$

Rumah (PR).

$8 \quad 8 \quad 3$

29,67

80,2

Pada tes hasil belajar siklus 2, siswa mengerjakan tes dengan sungguh-sungguh dan sangat teliti. Hal ini menyebabkan hasil yang diperoleh meningkat dari siklus 1, meskupun masih ada siswa yang belum tuntas. Penyebab tidak tuntasnya siswa tersebut dikarenakan siswa tersebut masih sering melakukan aktivitas lain saat proses pembelajaran berlangsung. Hal ini menjadi penyebab utama kurangnya pemahaman materi dari siswa yang belum tuntas. Hasil belajar pada siklus 2 meningkat dibanding siklus 1 . Peningkatan dapat dilihat dari persentase ketuntasan siswa pada siklus 1 (Tabel) dan siklus 2 (Tabel). Persentase ketuntasan pada siklus 2, yaitu $86,48 \%$ telah memenuhhi target keberhasilan. Berdasarkan peningkatan tersebut, maka model pembelajaran kooperatif tipe Numbered Head Together (NHT) dapat meningkatkan hasil belajar matematika siswa dengan persentase ketuntasan siswa di atas $85 \%$.

\section{Kesimpulan}

Berdasarkan hasil observasi, siswa yang melakukan proses pembelajaran menggunakan model NHT mengalami perubahan yang positif. Perubahan tersebut dilihat dari segi prestasi, interaksi, sikap, dan kemampuan siswa dalam menyelesaikan soal matematika secara individu sebagai dampak positif terhadap hasil belajar kelompok. Skor rata-rata hasil belajar matematika meningkat, yaitu 82,14 dan berada pada kategori tinggi dengan persentase ketuntasan sebesar $86,48 \%$.

\section{Referensi}

Alie, N. H. (2013). Penggunaan Model Pembelajaran Kooperatif Tipe NHT untuk Meningkatkan Hasil Belajar Siswa Kelas X2 SMA Neg. 3 Gorontalo Pada MAteri Jarak pada Bangun Ruang. Jurnal Entropi, 583592.

Daryanto, \& Rahardjo, M. (2012). Model Pembelajaran Inovatif. Malang: Gava Media.

Fonica, R., Gusmaweti, \& Deswati, L. (2013). Penerapan Model Pembelajaran Kooperatif Tipe Numbered Head Together (NHT) Dalam Pembelajaran Biologi di KElas VIII SMPN 32 Padang. Jurnal Fakultas Keguruan dan Ilmu Pendidikan.

Manurung, Widyastuti, I., Mulyani, B., \& Saputro, S. (2013). Pengaruh Penggunaan Model Pembelajaran Kooperatif Numbered Head Together (NHT) dan Learning Together (LT) dengan Melihat Kemampuan Materi Peserta Didik Terhadap Prestasi Belajar Peserta Didik pada Materi Tata Nama Senyawa Kimia Kelas X SMAN 2 Karanganyar. Jurnal Pendidikan Kimia (JPK).

Mulyadi. (2010). Diagnosis Kesulitan Belajar dan Bimbingan Terhadap Kesulitan Belajar Khusus. Yogyakarta: Nuha Litera.

Sabri, A. (2007). Strategi Belajar Mengajar \& Micro Teaching. Ciputat: Quantum Teaching.

Sanjani, M. A. (2020). Tugas dan Peranan Guru Dalam Proses Peningkatan Belajar Mengajar. Jurnal Serunai IImu Pendidikan, 35-42.

Siregar, N. R. (2017). Persepsi Siswa pada Pelajaran Matematika: Studi Pendahuluan pada Siswa yang Menyenangi Game. Prosiding Temu Ilmiah Nasional X Ikatan Psikologi Perkembangan Indonesia (hal. 224-232). Semarang: Jurnal Unissula. 
Taniredja, T., Pujiati, I., \& Nyata. (2012). Penelitian Tindakan Kelas untuk Pengembangan Profesi Guru: Praktik, Praktis, dan Mudah. Bandung: Alfabeta.

Widodo, S., Sukiswo, S., \& Putra, N. M. (2011). Penerapan Pembelajaran Kooperatif Model Numbered Head Together Untuk Meningkatkan Hasil Belajar Siswa Kelas VII SMP pada Pokok Bahasan Besaran dan Pengukuran. Jurnal Pendidikan Fisika Indonesia, 42-46. 